\title{
Analisis Prediksi Sebaran Nilaparvata Lugens (Hama Wereng) Tanaman Padi menggunakan Teknologi Autonomous Drone Mapping dengan Ground Sampling Area
}

\section{Prediction Analysis of Nilapartava Lugens Distribution of Rice using Autonomous Drone Mapping Technology with Ground Sampling Area}

\author{
Ahmad Rofi'i\#1, Dafid Ari Prasetyo ${ }^{* 2}$, Maria Azizah ${ }^{\# 3}$ \\ ${ }^{\# 1}$ Program Studi Teknologi Rekayasa Mekatronika Jurusan Teknik \\ Politeknik Negeri Jember \\ ${ }^{1}$ rofiidpolije.ac.id \\ *2 Program Studi Teknik Energi Terbarukan Jurusan Teknik \\ Politeknik Negeri Jember \\ ${ }^{2}$ dafidepolije.ac.id \\ ${ }^{\# 3}$ Program Studi Teknik Produksi Benih Jurusan Produksi Pertanian \\ Politeknik Negeri Jember \\ ${ }^{3}$ maria_azizah@polije.ac.id
}

\begin{abstract}
The purpose of this study was to help farmers predict the spread of rice planthopper pests by utilizing Autonomous Drone Mapping technology with Ground Sampling Area. The object under study was rice farming land with an area of $64.5 \mathrm{~m}^{2}$ which often experienced disturbances in productivity and quality of rice. Autonomous Drone Mapping Technology with Ground Sampling Area integration. This technology is used to detect the spread of leafhoppers on agricultural land through mapping of the affected land through a map of conditions resulting from shooting and imagery produced by drones flown over agricultural land. This technology can help rice farmers to predict pest attack from an early age by handling and preventive measures so that the level of productivity and quality of rice is not compromised. Prediction analysis can take advantage of remote imaging photos from the use of Autonomous Drone Mapping with Ground Sampling Area by analyzing the spread prediction data with Tren Forecasting Prediction. Based on the analysis of the predictions from the photo of the spread of planthopper pests, the distribution formula is $y=25.396 \ln (x)-34.948$ with the maximum spread of leafhoppers occurring on the 49th day so that serious handling is needed by farmers..
\end{abstract}

Keywords- Autonomous Drone Mapping, Ground Sampling Area 


\section{Pendahuluan}

Penyebaran serangan hama wereng pada lahan pertanian menjadi masalah klasik yang masih belum terpecahkan. Hama wereng merupakan hama padi yang paling berbahaya dan merugikan, khususnya di Indonesia karena serangga kecil ini menghisap cairan tanaman padi yang sekaligus menyebarkan virus yang menyebabkan tanaman padi terinfeksi penyakit tungro sehingga mengakibatkan gagal panen. Saat ini tanaman padi di Indonesia sangat rentan terhadap hama wereng. Hal tersebut terbukti dengan beberapa tahun kasus yang meresahkan petani akibat mewabahnya hama wereng. Berdasarkan data luas panen, produksi dan produktivitas padi menurut provinsi tahun 2018-2020 merilis bahwa terjadi penurunan luas panen padi dari 2018 hingga 2020 sebesar $11.377 .934,44$ ha menjadi $10.786 .814,17$ ha, sedangkan produktivitas panen padi juga mengalami penurunan drastis dari 59.200.533,72 ton menjadi 55.160.548, 20 ton [1]. Penurunan tersebut dikarenakan banyak faktor, salah satu faktor yang banyak merugikan dan menjadi perhatian khusus petani adalah penyebaran hama wereng yang berujung pada menurunnya produktifitas tanaman padi hingga gagal panen. Salah satu jensi wereng yang banyak menyebar adalah jenis wereng coklat (Nilaparvata Lugens). Jenis hama tersebut merupakan golongan insekta yang bekerja dengan menghisap cairan tanaman yang dapat mengakibatkan daun berubah kuning oranye sebelum coklat dan mati. Jenis hama tersebut juga dapat menularkan penyakit kerdil hampa dan rumput yang sampai saat ini belum bisa diatasi. Hama jenis ini dapat bertahan sepanjang musim pada daerah tropis dan akan terjadi peningkatan populasi pada kelembapan dan suhu optimum $28^{\circ} \mathrm{C}-30^{\circ} \mathrm{C}$, intensitas cahaya rendah serta pemupukan $\mathrm{N}$ yang tinggi, lahan basah dan dominasi faktor iklim [2].

Berbagai cara telah dilakukan untuk dapat mengendalikan dan mengatasi penyebaran hama tersebut. Cara yang dapat dilakukan dengan mengintegrasikan metode fisik dan mekanik [3]. Metode lain juga telah dilakukan dengan cara pengendalian dan keseimbangan ekosistem [4]. Bahkan banyak petani yang memberikan pestisida yang tak terkendali sehingga dapat berdampak pada ketidakseimbangan ekosistem. Merujuk pada kenyataan tersebut, maka penyebaran hama wereng tanaman padi menjadi ancaman bagi meningkatnya produktifitas pertanian terutama padi sehingga dibutuhkan terobosan peran teknologi yang dapat membantu petani dalam mengatasi penyebaran hama wereng (Nilapartava Lugens) tanaman padi sehingga tidak sampai mengganggu pertumbuhan tanaman padi.

Salah satu pengembangan teknologi yang dapat membantu petani dalam mengatasi penyebaran hama hama wereng (Nilapartava Lugens) tanaman padi adalah dengan memanfaatkan fungsi teknologi autonomous drone mapping yang diintegrasikan dengan Ground Sampling Area yang dapat digunakan untuk mendeteksi penyebaran hama wereng sehingga dapat dilakukan penanganan lebih lanjut untuk meningkatkan produktifitas dan minimal mengurangi dampak kegagalan panen.

\section{A. Sistem Kerja Autonomous Drone}

Sistem kerja autonomous drone diterbangkan secara otomatis sesuai dengan misi yang diberikan yaitu di lahan pertanian padi dan mengambil gambar pada ketinggian tertentu sehingga diperoleh gambar penampakan lahan pertanian yang ditamani padi. Gambar yang diperoleh kemudian digabung dengan koordinat GPS pada georeferens. Melalui software agisoft dan disimpan dalam bentuk .tif, maka akan memberikan gambaran secara riil kondisi penyebaran hama wereng di suatu lahan pertanian melalui peta buta dengan keterangan pada peta menggunakan arcgis. Dengan gambaran penampakan peta penyebaran hama wereng yang dihasilkan. Dalam bidang pertanian, sistem kerja Autonomous dapat menghasilkan data berupa tampilan citra lahan seperti pada contoh gambar 1 [5].

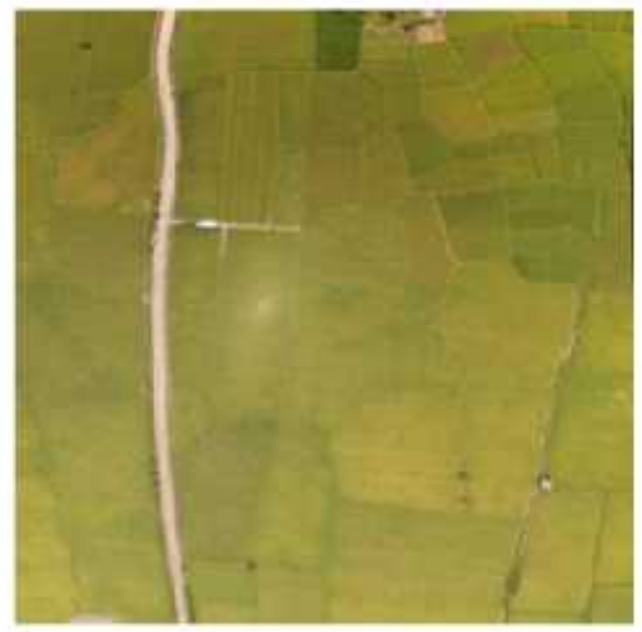

GAMBAR 1. TAMPILAN HASIL KERJA AUTONOMOUS PADA LAHAN PERTANIAN

\section{METODOLOG}

\section{A. Gambaran IPTEK}

Teknologi Autonomous Drone Mapping dengan integrasi Ground Sampling Area dan Fotogrametry. Teknologi tersebut dimanfaatkan untuk mendeteksi penyebaran hama wereng pada lahan pertanian melalui pemetaan lahan yang terdampak melalui peta kondisi hasil pemotretan dan pencitraan yang dihasilkan oleh drone yang diterbangkan di atas lahan pertanian. Teknologi tersebut juga didesain dengan 
Ahmad Rofi'I, Dafid Ari Prasetya, Maria Azizah. Analisis Prediksi Sebaran Nilaparvata Lugens (Hama Wereng) Tanaman Padi Menggunakan Teknologi Autonomous Drone Mapping dengan Graound Sampling Area

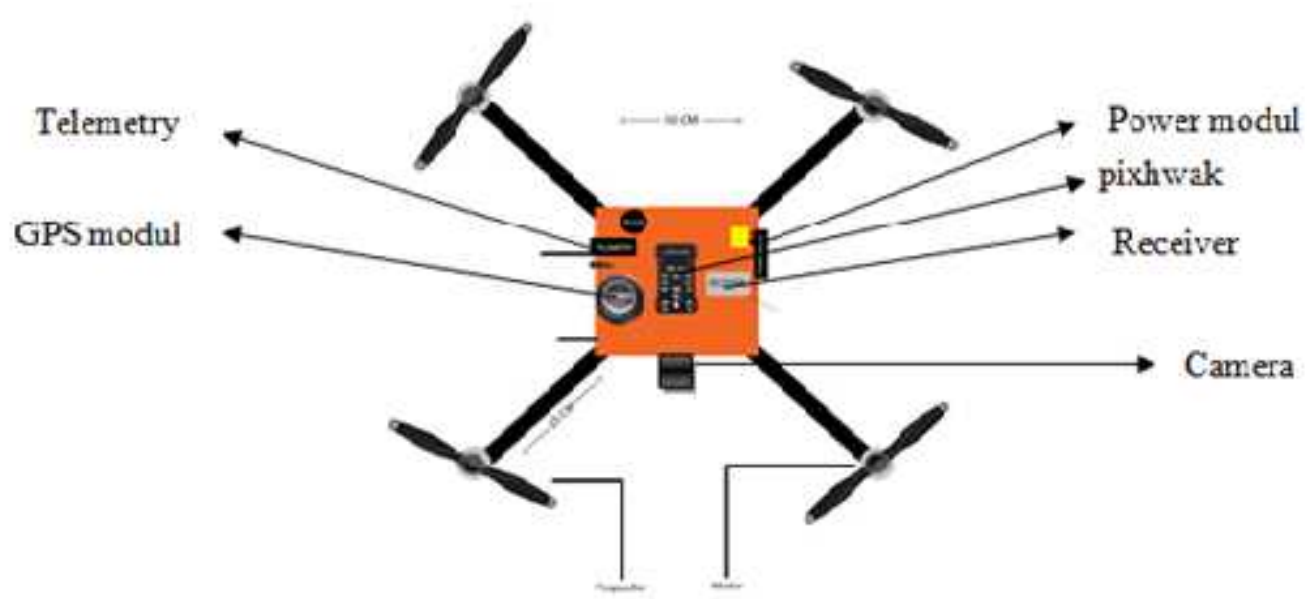

Gambar 2. Desain Autonophous Drone Mapping

jangkauan yang maksimum sehingga mampu menjangkau lahan pertanian yang terdampak penyebaran hama wereng. Teknologi yang digunakan disertai dengan komponen camera mirroless A6000 yang digunakan untuk mengambil gambar secara automotis sesuai dengan inputan dari pixhawk, yang nantinya hasil dari pengambilan gambar diolah dengan log GPS agar foto tersebut mendapatkan koordinat, sehingga dapat di proses untuk pembuatan peta buta. Sedangkan Pixhawk merupakan sebuah mikrokontroller utama dalam drone yang berfungsi untuk membaca sensor seperti gyro untuk menyeimbangkan dan menstabilkan drone, kompas untuk arah hadap drone dan perangkat lainnya yang terhubung dengan pixhawk. Pixhawk sendiri dapat di isikan sebuah misi otomatis yang dapat terbang secara outonomous tanpa harus dikontrol manual dengan pilot drone. Komponen pendukung lain pada teknologi ini adalah pixhwak, telemetry, banana plug, motor brushless, PDB serta GPS 3DR yang terintegrasi dalam satu sistem.

\section{B. Alat dan Bahan} lain;

Alat yang digunakan pada penelitian ini antara

- Telemetry,

- GPS modul,

- Power modul,

- Pixhwak, Receiver,

- camera

- komponen elektronika.

Bahan yang digunakan pada penelitian ini adalah peta dasar lahan petakan sawah yang akan diteliti dan sampel sawah pertanian tanaman padi.

\section{Tempat dan Waktu Penelitian}

Tempat yang dijadikan sebagai area penelitian adalah lahan pertanian di Jl. Teuku Umar Kelurahan Kebonsari yang ditanami padi dan telah dilakukan observasi serta interviuw awal pada pemilik lahan pertanian bahwa sering mengalami gagal panen dikarenakan penyebaran hama wereng pada tanaman padi. Luas lahan yang diamati adalah $64,5 \mathrm{~m}^{2}$.

Waktu pengamatan yang dilakukan adalah sebanyak 3 kali dengan jarak 5 hari pada setiap pengamatan. Pada setiap pengamatan dilakukan pengambilan foto citra lahan sawah pertanian dengan penginderaan stereoskopis yang diambil dari Autonomous Drone Mapping pada ketinggian 50 meter. Data foto citra yang diperoleh akan dianalisa berdasarkan luasan perubahan warna pada lahan pertanian. Pengukuran luasan lahan dapat dilakukan dengan membatasi ukuran daerah yang terserang hama dengan menggunakan pencitraan ukuran pengideraan jauh .

\section{Metode}

Metode penelitian yang digunakan adalahmetode deskriptif dengan stereoskopis. Metode stereoskopis atau yang dikenal dengan anaglyph image merupakan metode pencitraan suatu obyek dengan sudut pandang jauh karena setiap mata manusia memiliki sudut pandang yang berbeda dari citra yang dihasilkan [6]. Metode deskriptif pada penelitian ini menekankan pada analisa perubahan peta penyebaran hama wereng dengan indikator perubahan warna tanaman padi sesuai dengan indikator yang ditentukan. Perubahan warna yang ditemukan dari foto jarak jauh oleh Autonomous Drone Mapping kemudian ditentukan ukuran dan luas lahan yang terserang dan tidak terserang hama. Data diperoleh selama 3 kali perbedaan dengan persumaan:

$$
\Delta A=A_{0}-A_{1}
$$

Dengan $\Delta A=$ Luas lahan tak terserang hama $\left(\mathrm{m}^{2}\right)$

$A_{0}=$ Luas lahan semula $\left(\mathrm{m}^{2}\right)$

$A_{1} \quad=$ Luas lahan terserang $\left(\mathrm{m}^{2}\right)$

Dan prosentase penyerangan hama wereng: 


$$
\% A=\frac{A_{1}}{A_{0}} \times 100 \%
$$

Untuk dapat mengetahui perkiraan penyebaran yang akan terjadi pada kurun waktu selanjutnya, maka dilakukan analisa prediksi dengan bantuan Tren Forecasting Prediction melalui grafik dan formula yang dihasilkan.

\section{E. Alir Kegiatan Penelitian}

Langkah-langlah kerja metode penelitian dapat disajikan melalui alir kegiatan penelitian sebagai berikut:

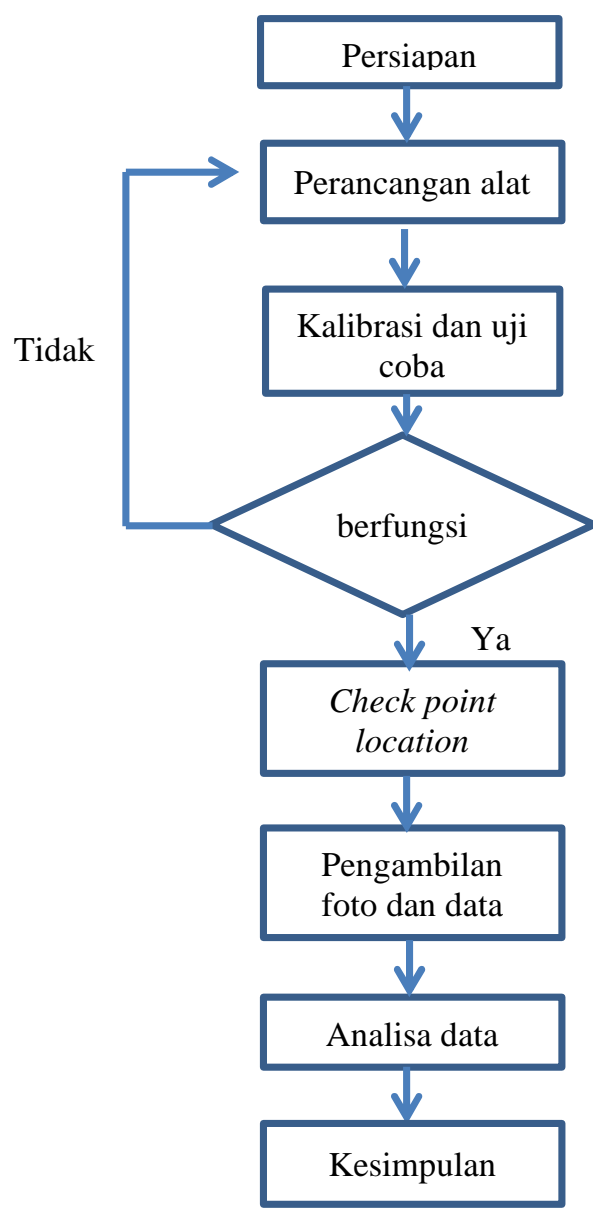

Gambar 3. Diagram Alir Penelitian

1) Perancangan alat dan kalibrasi; Alat dengan pemanfaatan teknologi Autonomous Drone Mapping dengan Ground Sampling Area dibuat dengan melengkapkan beberapa komponen antara lain; GPS modul, Power modul, Camera, pixhwak dan telemetry. Masing-masing memiliki fungsi yang mendukung proses kerja secara sistematis. Motor Brushless adalah jenis motor yang mengubah energi listrik menjadi energi gerak. Yang berfungsi untuk memutar baling - baling (Propeller) agar dapat menghasilkan daya angkat terhadap beban pada drone. Pixhawk adalah sebuah mikrokontroller utama dalam drone yang berfungsi untuk membaca sensor seperti gyro untuk menyeimbangkan dan menstabilkan drone, kompas untuk arah hadap drone dan perangkat lainnya yang terhubung dengan pixhawk. Pixhawk sendiri dapat di isikan sebuah misi otomatis yang dapat terbang secara outonomous tanpa harus dikontrol manual dengan pilot drone. Esc (Elektrik Speed Control) berfungsi untuk menerima sinyal Output yang diberikan oleh Pixhawk yang dirubah dari sinyal PWM (Pulse Width Modulation) ke bentuk tegangan agar dapat menghidupkan ke empat motor yang terpasang pada drone.Telemetry merupakan perangkat tambahan yang berfungsi untuk pertukaran data antara data pixhawhk maupun dari GCS (Ground Control Point) agar dapat memonitor pergerakan dari drone saat terbang autonomous dan meminimalisirkan terjadinya kecelakaan pada drone. Untuk menentukan navigasi sistem dibutuhkan GPS. GPS (Global Positioning System) berfungsi untuk navigasi pada drone serta untuk mengunci keberadaan drone berdasarkan latitude dan longtitude. Camera sony A6000 digunakan untuk mengambil gambar secara automotis sesuai dengan inputan dari pixhawk, yang nantinya hasil dari pengambilan gambar diolah dengan log GPS agar foto tersebut mendapatkan kordinat, sehingga dapat di proses untuk pembuatan peta buta. Pengambilan citra pada ketinggian 50 meter.

2) Pengambilan Data Citra dan Data Lapangan; Setelah alat Autonomous Drone Mapping telah selesai dirancang dan telah dikalibrasi, maka selanjutnya dilakukan pengambilan data lapangan berupa foto citra jarak jauh yang diambil melalui Autonomous Drone Mapping yang diterbangkan pada ketinggian 50 meter. Pada ketinggian tersebut, maka akan ditemukan derajat posisi lahan pertanian yang akan diamati. Ilustrasi pengambilan data dapat dijelaskan pada gambar 4 berikut: 
Ahmad Rofi'I, Dafid Ari Prasetya, Maria Azizah. Analisis Prediksi Sebaran Nilaparvata Lugens (Hama Wereng) Tanaman Padi Menggunakan Teknologi Autonomous Drone Mapping dengan Graound Sampling Area

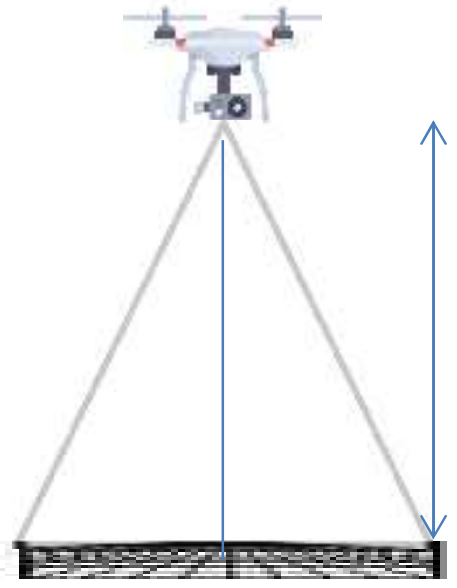

50 meter

GAMBAR 4. ILUSTRASI PENGAMBILAN DATA

Data yang sudah diperoleh dari pengambilan foto secara pengideraan jauh oleh Autonomous Drone Mapping selanjutya dilakukan pengukuran dan analisa luas wilayah yang mengalami penyebaran hama wereng dilihat dari perubahan warna dari faktor penyebaran hama.

3) Analisa Ukuran dan Area Lahan Penyebaran Hama Wereng; Lahan yang sudah difoto melalui pengindraan foto oleh Autonomous Drone Mapping dan pengukuran luas lahan yang mengalami perubahan warna akibat penyebaran hama wereng.

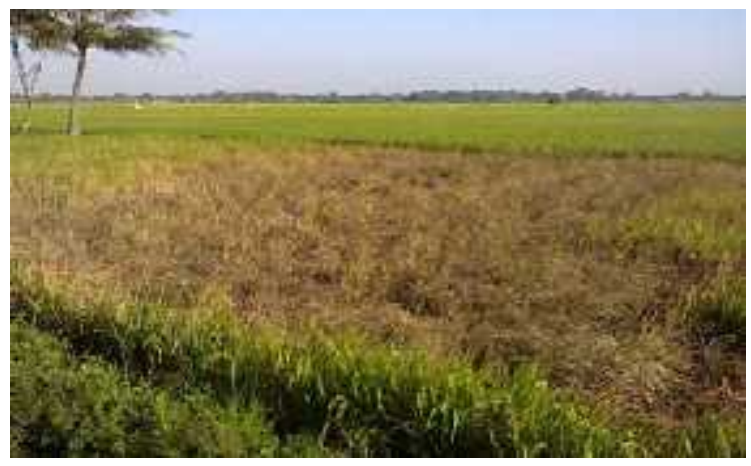

GAMBAR 5. PERUBAHAN WARNA LAHAN TERSERANG HAMA

Untuk selanjutnya dilakukan pengukuran melalui penginderaan jauh ukuran dan area oleh ukuran pengideraan jauh dengan menentukan point awal hingga akhir area yang mengalami perubahan warna karena penyebaran hama wereng.

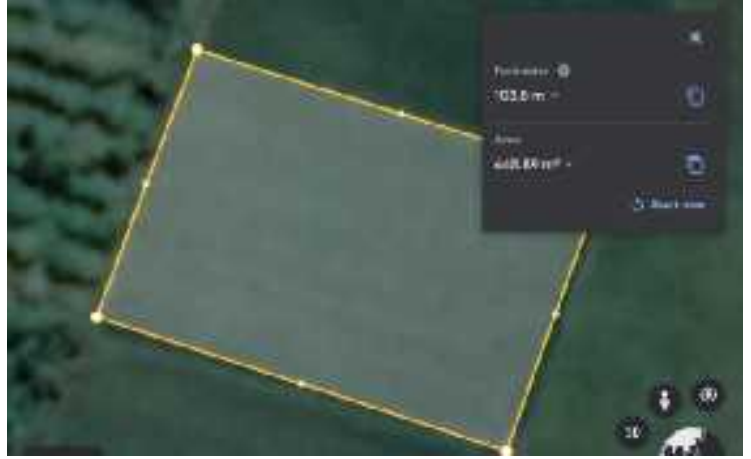

GAMBAR 6. PENENTUAN POINT UKURAN DAN AREA LAHAN YANG MENGALAMI PERUBAHAN WARNA

Foto hasil penginderaan jauh melalui Autonomous Drone Mapping yang telah diketahui ukuran dan luasnya selanjutnya diubah menjadi hitam putih untuk lebih mengetahui sketsa perubahan warna agar lebih tampak.

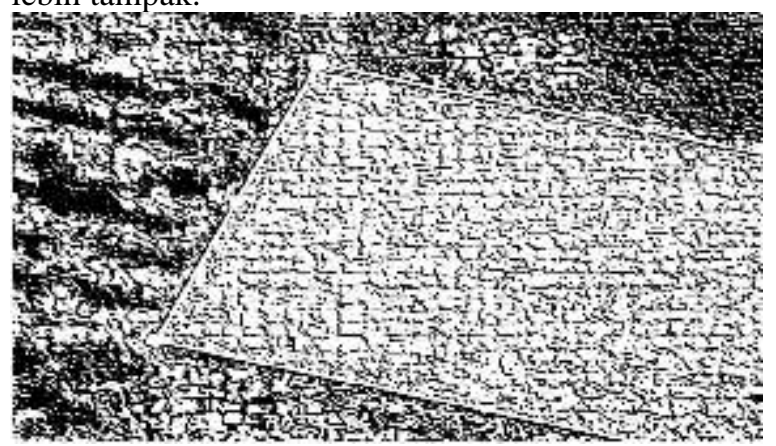

GAMBAR 7. PERUBAHAN SKETSA HASIL TAMPILAN HITAM PUTIH LAHAN

\section{III.HASil DAN PEMbahasan}

\section{A. Hasil Foto Penampakan Lahan Pertanian}

Setelah alat Autonomous Drone Mapping telah dirancang berdasarkan sesuai dengan desain yang telah dibuat, selanjutnya dilakukan kalibrasi serta uji coba penggunaan di lapangan. Berdasarkan hasil pengamatan, kalibrasi dan evaluasi alat sesuai fungsinya dapat disimpulkan bahwa Autonomous Drone Mapping dapat berfungsi dengan baik sesuai dengan fungsinya.

Dengan telah berfungsinya Autonomous Drone Mapping, maka selanjutnya dilakukan pengambilan data di lapangan yaitu sawah yang menanam padi pada lahan seluas $64,5 \mathrm{~m}^{2}$. 


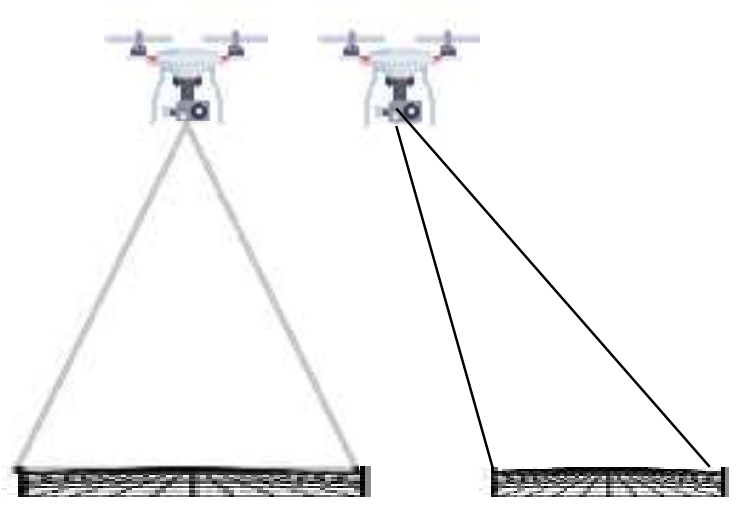

GAMBAR 8. POSISI PENGAMBILAN KENAMPAKAN FOTO

Kenampakan foto yang dihasilkan setelah dilakukan proses seleksi tampak pada gambar 9 berikut:

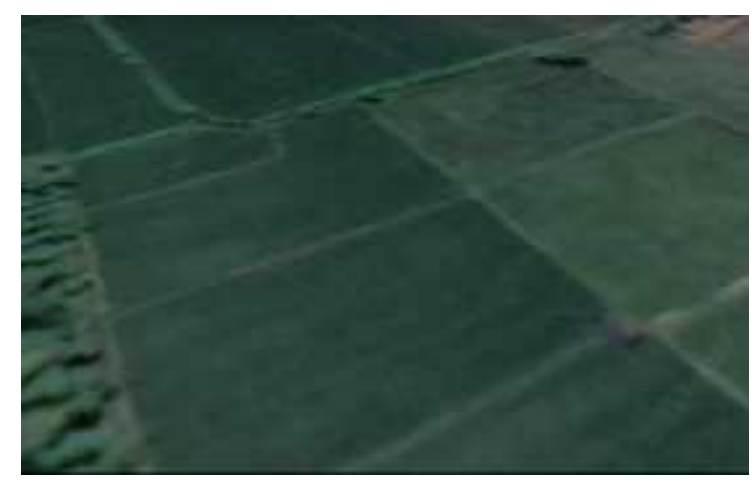

GAMBAR 9. KENAMPAKAN FOTO LAHAN

Derajat point area yang akan diamati terletak pada posisi $8^{0} 11^{\mathrm{I}} 20^{\mathrm{II}} \mathrm{S} 113^{0} 41^{\mathrm{I}} 39^{\mathrm{II}} \mathrm{E}$. Setelah ditentukan point area lahan yang akan diamati, maka dilakukan pengamatan dan pengambilan data lapangan berupa foto jarak jauh melalui Autonomous Drone Mapping. Pengambilan foto diambil beberapa kali kemudian diseleksi dengan tingkat kejelasan gambar sehingga dapat diamati dengan jelas warna yang akan diukur dan ditentukan luas lahan yang terserang hama.

Dengan menggunakan pengukuran ukuran pada point area yang terserang melalui pengideraan jauh diperoleh data dari tampilan penginderaan jauh diperoleh tampilan sebagai berikut:

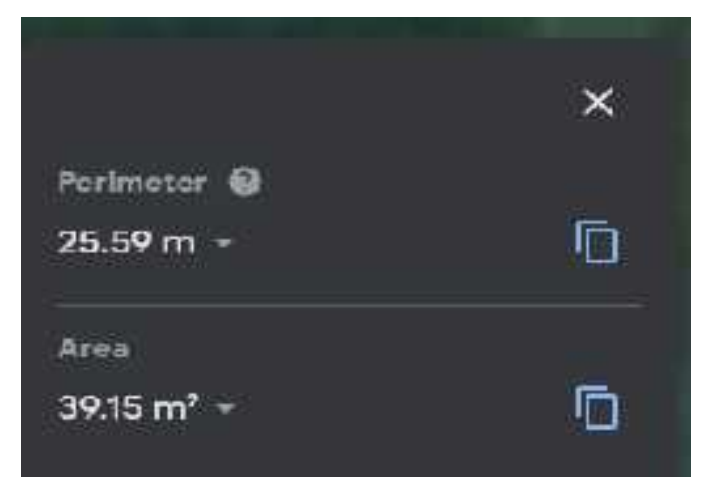

GAMBAR 10. TAMPILAN UKURAN LAHAN

\section{B. Pengolahan dan Analisa Data}

Data yang diperoleh dari hasil foto dan data pengukuran luas lahan yang terserang hama wereng selanjutnya dianalisa dengan bantuan Tren Forecasting Prediction melalui grafik dan formula yang dihasilkan.

TABEL 1. HASIL PEROLEHAN DATA LUAS DAN KELILING LAHAN TERSERANG HAMA WERENG

\begin{tabular}{ccc}
\hline Pengamatan ke & Keliling $(\mathbf{m})$ & Luas $\left(\mathbf{m}^{\mathbf{2}}\right)$ \\
\hline 1 & 16,02 & 15,09 \\
2 & 25,59 & 39,15 \\
3 & 30,42 & 40,35 \\
\hline
\end{tabular}

Dengan luas lahan semula $645 \mathrm{~m}^{2}$, maka akan diperoleh prosentase penyebaran hama wereng pada lahan pertanian.

$$
\begin{aligned}
& \text { Pengamatan } 1=\frac{15,09}{645} \times 100 \%=2,34 \% \\
& \text { Pengamatan } 2=\frac{39,15}{645} \times 100 \%=6,07 \% \\
& \text { Pengamatan } 3=\frac{40,35}{645} \times 100 \%=6,26 \%
\end{aligned}
$$

Dengan memperhatikan data yang diperoleh, selanjutnya dilakukan analisa data prediksi penyebaran dengan Tren Forecasting Prediction. 
Ahmad Rofi'I, Dafid Ari Prasetya, Maria Azizah. Analisis Prediksi Sebaran Nilaparvata Lugens (Hama Wereng) Tanaman Padi Menggunakan Teknologi Autonomous Drone Mapping dengan Graound Sampling Area

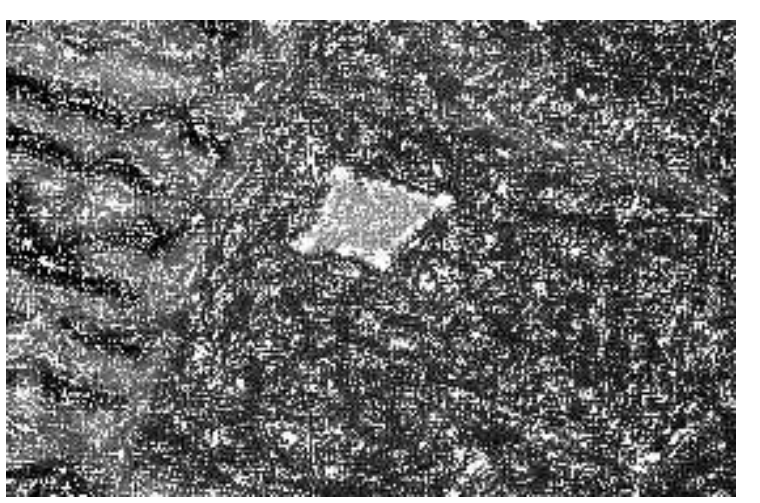

Area terserang hama pengamatan ke 1 (5 hari setelah pengamatan awal)

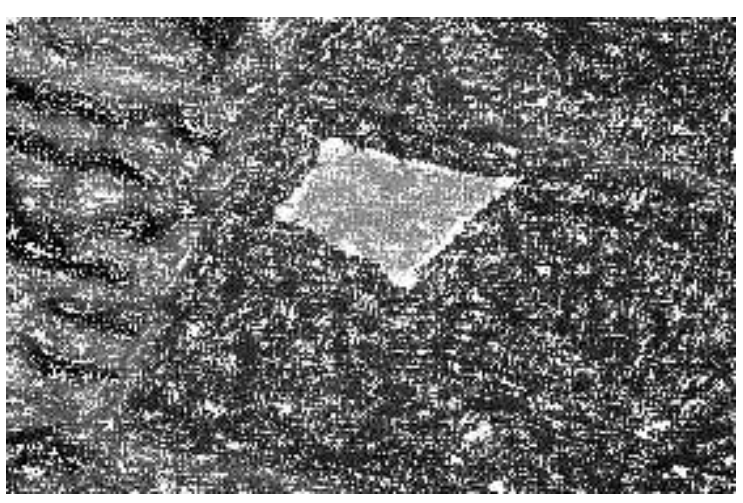

Area terserang hama pengamatan ke 2 (5 hari setelah pengamatan ke -1)

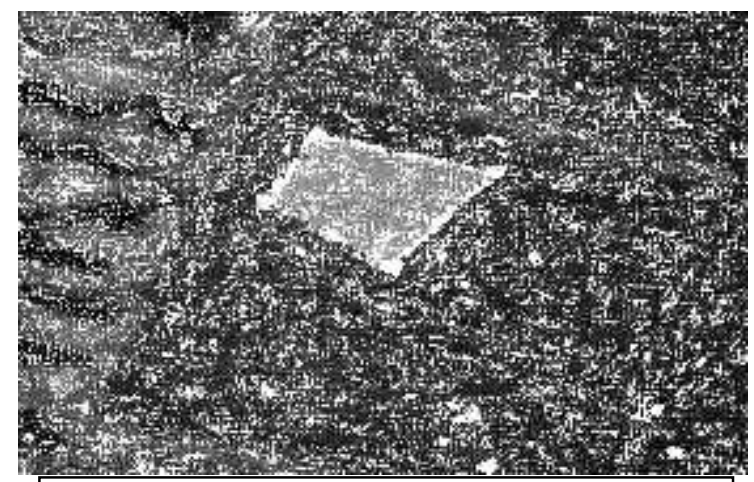

Area terserang hama pengamatan ke 3

( 5 hari setelah pengamatan ke -2 )

GAMBAR 11. KENAMPAKAN AREA TERSERANG HAMA DENGAN SKETSA HITAM PUTIH

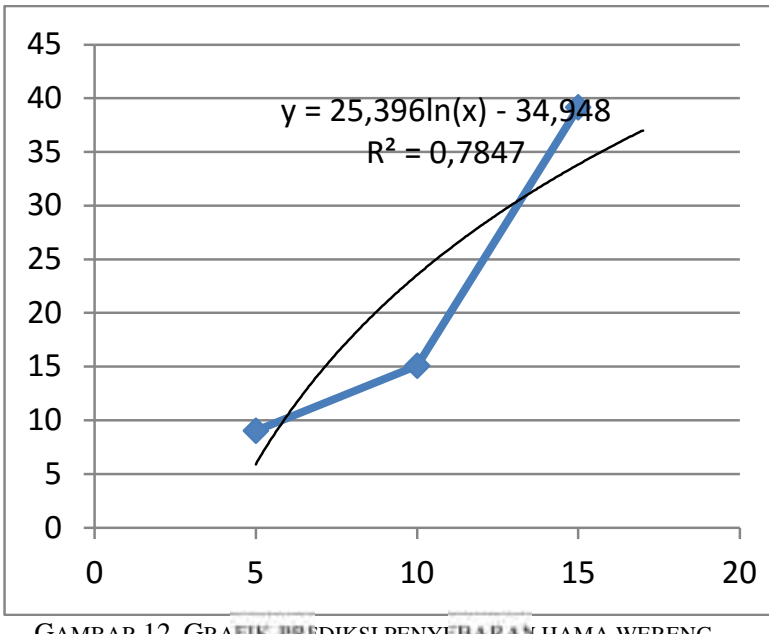

GAMBAR 12. GRAFIK JREDIKSI PENYIBARAN HAMA WERENG

Prediksi penyebaran hama wereng dapat diformulasikan $y=25,396 \ln (x)-34,948$ dengan $\mathrm{x}$ adalah waktu pengamatan (hari). Jika dapat diprediksikan dari formula tersebut, maka dapat diprediksikan tingkat penyebaran hama wereng pada waktu tertentu. Misalkan pada hari ke 30 akan dapat diprediksi luas penyebaran hama wereng adalah

$$
\begin{aligned}
& y=25,396 \ln (x)-34,948 \\
& y=25,396 \ln (30)-34,948 \\
& y=25,396 \times 3,40-34,948 \\
& y=51,43 \mathrm{~m}^{2}
\end{aligned}
$$

Hal yang sama juga dapat diprediksi penyebaran hama wereng apabila tidak dilakukan penanganan secara alami ataupun kimiawi pada lahan. Dengan menggunakan formula tersebut, juga dapat dianalisa prediksi penyebaran hama wereng pada lahan pertanian tersebut akan mencapai titik maksimal pada waktu tertentu yaitu

$$
\begin{gathered}
y=25,396 \ln (x)-34,948 \\
\ln x=\frac{y+34,948}{25,396} \\
x=e^{\frac{y+34,948}{25,396}} \\
x=e^{\frac{64,5+34,948}{25,396}} \\
x=49
\end{gathered}
$$

Jika luas lahan $64,5 \mathrm{~m}^{2}$, maka dapat diprediksi waktu penyebaran maksimum pada hari ke 49 . Analisa prediksi tersebut tergantung dengan perlakuan yang diberikan untuk mengatasi 
penyebaran hama wereng sebelum tingkat penyebaran meningkat.

\section{Kesimpulan}

Dari hasi penelitian dapat disimpulkan bahwa penyebaran hama wereng pada tanaman padi dapat diprediksi tingkat penyebarannya dengan memanfaatkan teknologi Autonomous Drone Mapping dengan Ground Sampling Area. Teknologi tersebut dapat membantu petani padi untuk dapat memprediksi penyerangan hama sejak dini dengan melakukan penanganan dan tindakan preventif sehingga tingkat produktivitas dan kualitas padi tidak terganggu. Analisis prediksi dapat memanfaatkan foto pencitraan jarak jauh dari pemanfaatan Autonomous Drone Mapping dengan Ground Sampling Area dengan analisa data prediksi penyebaran dengan Tren Forecasting Prediction. Berdasarkan analisa prediksi dari foto penyebaran hama wereng diperoleh formula penyebaran $y=$ $25,396 \ln (x)-34,948$ dengan tingkat penyebaran hama wereng maksimum terjadi pada hari ke 49 sehingga dibutuhkan penanganan secara serius oleh petani.

\section{UCAPAN TERIMA KASIH}

Penulis berterimakasih kepada petani yang memiliki lahan pertanian di Jl. Teuku Umar Kelurahan Kebonsari Kecamatan Sumbersari yang telah memberikan kesempatan dan ijin tempat dalam pelaksaan penelitian. Penulis juga mengucapkan terima kasih pada P3M Politeknik Negeri Jember atas dukungan terlaksananya kegiatan penelitian.

\section{DAFTAR PUSTAKa}

[1]. BPS (2020). Peningkatan Produksi Padi Nasional. http://www.bps.go.id/tnmn.pgn.php.

[2]. Sianipar, M.H, Djaya, L, Santosa, E, Soesilohadi, R. C, Natawigena, W.D, Ardiansyah, M (2015). Populasi Hama Wereng Batang Coklat (Nilaparvata Lugens Stal.) Dan Keragaman Serangga Predatornya Pada Padi Sawah Lahan Dataran Tinggi Di Desa Panyocokan, Kecamatan Ciwidey, Kabupaten Bandung. Jurnal Agrikultura 26 (2): 111-121

[3]. Sjakoer, NAA. 2010. Mortalitas Hama Wereng Punggung Putih Setelah dimangsa oleh Serangga Predator (Pengamatan Visualisasi di Green House).Jurnal El-Hayah 1(2) : pp. 35-39.

[4]. Syahrawati, M. Busniah dan N. Nelly. 2010. Sosialisasi Teknik Konservasi Musuh Alami Wereng Coklat (Nilaparvata lugens) pada Petani Perempuan. Lembaga Pengabdian kepada Masyarakat Universitas Andalas. Padang.

[5]. Shofiyanti, Rizatus. 2011.Teknologi Pesawat Tanpa Awak untuk Pemetaan dan Pemantauan Tanaman dan Lahan Pertanian. Bogor.

[6]. Ivan, Michael. W. Gazali. N. Imanuel. 2012. Aplikasi Perubahan Citra 2D Menjadi 3D dengan Metode Stereoscopic Anaglyph berbasiskan Komputer. Universitas Bina Nusantara: Jakarta. 